\title{
Evaluation for Ant Financial Group's Investment Value Based on POCD analysis
}

\author{
Zijian $\mathrm{Ma}^{1, *}$ \\ ${ }^{1}$ Department of Economics, University of Washington Seattle, Seattle, US \\ *Corresponding author. Email: guanghua.ren@gecacdemy.cn
}

\begin{abstract}
In recent years, Internet finance has flourished and has a considerable market. Therefore, more and more people want to invest in this industry to make money. Among the many Internet finance companies, Ant Financial is the most attractive to investors. The subject of our research is the feasibility of investing in Ant Financial. We conducted a comprehensive analysis from multiple perspectives such as industry, company, and country. Industry factors are considered from the current situation and future industry development trends; corporate factors are explored from company development, company scale, data information, etc.; national factors are considered from aspects of policy formulation, laws, and regulations, etc. In addition, we also use the POCD analysis method to increase the credibility of the research more rigorously. After research, we believe that now is not a good time to invest in Ant Financial. This paper hopes that people will make more accurate decisions about the feasibility of investing in Ant Financial. At the same time, let people know more about the investment environment of the Internet finance industry.
\end{abstract}

Keywords: POCD analysis, finance, Ant Financial, investment

\section{INTRODUCTION}

Internet finance is one of the fastest-growing emerging industries globally, and it is also the most popular industry among the younger generation[1-3]. It refers to a new financial business model in which traditional financial institutions and Internet companies use Internet technology and information communication technology to achieve financial communication, payment, investment, and intermediary information services [4]. So far, it can be roughly divided into six major Internet financial models: third-party payment, P2P online lending, big data finance, crowdfunding, information-based financial institutions, and Internet financial portals

China's Internet finance can be roughly divided into three stages of development: the first stage is the Internetization stage of the traditional financial industry from the 1990s to 2005; the second stage is the booming stage of third-party payment around 2005-2012; the third stage is the development stage of substantial Internet financial services since 2012 [5]. In the development of Internet finance, domestic Internet finance has presented various business models and operating mechanisms. More and more investment institutions and ordinary investors are beginning to pay attention to and invest in Internet finance companies [6, 7]. Among them, we have to mention Ant Financial. The subject of our research is the investment prospects of Ant Financial.

This article analyzes the feasibility of investing in Ant Financial through companies, industries, and countries. In addition, we also use the POCD analysis method that is widely used in the financial field. Finally, we studied the feasibility of investing in Ant Financial based on the research mentioned above and concluded that it is not suitable for investment at this stage.

Section 1 introduces the company from many aspects, such as development history, data information, company size, Etc. Section 2, we use POCD analysis to analyze the investment prospects of Ant Financial. POCD refers to a method to examine whether a company is worth investing in from four aspects: relevant personnel, industry opportunities, industry environment, and transactions. Section 3, we combine the previous analysis and personal opinions to give relevant suggestions. Section 4 gives conclusions and related gains on related issues and deficiencies that need to be corrected in the future. 


\section{COMPANY DESCRIPTION}

\subsection{Development history}

The prototype of Ant Financial is Alipay, established by Alibaba Group in 2004. At the beginning of its establishment, it was to build Ali's third-party payment platform. In 2013, Alipay was formally independent of Alibaba Group, with it as the main body to establish a group aimed at helping small and micro enterprises and individuals handle financial services. Therefore, the group is often regarded as the predecessor of Ant Financial.

In July 2020, Ant Financial Service officially changed its name to Ant Group. Its subsidiaries have opened up payment (Alipay), wealth management (Ant Wealth, Yu'e Bao), financing services (Huabei, Borrowing), insurance, and credit services ) six business systems of digital upgrade solutions. In the same year, Ant Financial sought to be listed in China and Hong Kong simultaneously. Its IPO scale reached the world's largest IPO size of 34.3 billion U.S. dollars, and its valuation reached 2.1 trillion yuan (approximately 315 billion U.S. dollars). Nevertheless, in November last year, Ant Financial suddenly announced the suspension of listing and was subsequently interviewed by the Chinese government and has not yet been listed. So far, Ant Financial is still the world's largest unicorn company.

\subsection{Data information}

We collect the financial reports information of Ant Group. As a company that has attracted much attention since its inception, Ant Financial's operating income reached 65.4 billion yuan when it first announced its financial report in 2017. Its net profit reached 6.951 billion yuan in the same year. In 2018 and 2019, both operating income and net profit have seen an enormous increase. Operating income increased from 85.7 billion yuan to 120.6 billion yuan (a $40.72 \%$ increase), and net profit reached 16.96 billion yuan after experiencing a loss of as much as $90.4 \%$ in 2017-2018 (a net profit of 667 million yuan in 2018) (The increase reached $2442.73 \%$ ).

Table 1 The financial report's information of Ant Group (billion)

\begin{tabular}{lcccc}
\hline & 2017 & 2018 & 2019 & 2020 \\
\hline $\begin{array}{l}\text { Net } \\
\text { assets }\end{array}$ & 65.37 & 152.4 & 189.6 & 214.9 \\
$\begin{array}{l}\text { Total } \\
\text { assets }\end{array}$ & 133.7 & 237.1 & 271.6 & 315.9 \\
\hline
\end{tabular}

During the same period, Ant Financial's total assets and net assets continued to rise (Table 1). Total assets were 133.7 billion yuan (2017), 237.1 billion yuan
(2018), 271.6 billion yuan (2019), and 315.9 billion yuan (Q2 2020); net assets were 65.37 billion yuan (2017), 152.4 billion yuan (2018), 189.6 billion yuan (2019), and 214.9 billion yuan (Q2 2020). However, due to the forced delisting, Ant Financial has not released any financial status since the second quarter of 2020 .

\subsection{Company size}

According to data disclosed in August 2020, Ant Financial has 16,000 employees. Nearly 5,000 hold shares in the company (if the listing is successful, it will create thousands of millionaires or multimillionaires). The number of users of each of the company's core products is staggering. In 2018, the number of active Alipay users reached 870 million, providing payment services to more than 10 million small and micromerchants. In the same year, Huabei and Borrowan users exceeded 500 million, and Yu'ebao's assets under management reached 1.8 trillion. In addition to the six core businesses mentioned above, Ant Financial also involves artificial intelligence, risk control, security, and districts. Hard-core technology fields such as blockchain, computing, and technical infrastructure. At the same time, Ant Financial has 42 subsidiaries, of which 39 are holding subsidiaries. Ant Financial is now suspended from listing. However, it is estimated that if the listing is booming after the rectification, the valuation will still be more than RMB 1 trillion, which is still equivalent to the market value of a Fortune 500 company.

\section{POCD ANALYSIS}

POCD is often used to investigate whether a company can successfully start a business. The first part is people. To measure a company's success, then the most crucial factor is its founder. However, this also includes the company's employees, managers, investors, and other related personnel [8]. The second part is opportunity. In addition to people, then it is necessary to consider the probability of success. This includes issues such as the prospects of the company's industry and its rate of return. The third part is context. This factor is also critical because the company's industry-related policies and laws and regulations may change at any time. In addition, the investment prospects of the industry and the general environment were also considered. The fourth part is a deal. After all the current things are understood, the final profit distribution and the specific division of labor, rights, and obligations of both parties must be reflected explicitly in the contract.

\subsection{People}

People are the essential element of a company and the most critical factor to measure whether a company 
can succeed. Therefore, the talent pool is the most important thing for a company. At the beginning of its establishment, Ant Financial also encountered a shortage of talents, keeping it stagnant for a long time. However, the Ant Group has also learned from it and laid the foundation for becoming a world-class enterprise.

In 2004, Alipay (the predecessor of Ant Financial) was formally established to solve the development problems of Taobao under Alibaba. Its start-up team was born in the Internet industry, not in the financial industry. Taobao's start-up team found that ordinary people are very uneasy about online transactions. At that time, the Internet had just begun to develop in China, which also caused ordinary people to wait and see. The founders had no management or financial industry experience before, making the team think about future development trends across industries. In the end, the team used Internet thinking to solve this problem, that is, to build a third-party online payment platform called Alipay (probably the earliest concept of Internet finance in China). With the development of Alipay, with more and more customers and larger and larger volumes, the start-up team headed by Jack Ma began to seek more remarkable development.

In 2013, Alipay became China's largest online trading platform, thanks to the team's beginning to develop diversified and informative. At the same time, while maintaining its technological advantages, the team also began to attract members from different fields, including finance and management. In the following years, Ant Group began to be involved in different financial fields continuously. So far, Ant Financial has a large and complex team involving talents in many different aspects such as technology, finance, and management, and it has reached the world in the industry. Top-level.

\subsection{Opportunity}

The development prospects of the industry affect the company's probability of success. The Internet industry or the financial industry has a substantial undeveloped market and resources. It has a vast potential market in the future, which means that there will be a very high rate of return. However, the vast market has caused too many competitors, and the government cannot supervise the problems, and there are also significant risks.

From a macro perspective, the latest scientific and technological revolution of humanity is based on the Internet. It can be said that the future development trend of the Internet largely determines the future development direction of human civilization. Since ancient times, the financial industry has belonged to the essential human development industry, especially in the contemporary prospects of unprecedented rapid development of human civilization. From a micro perspective, everyone's food, clothing, housing, and transportation are now unable to leave the help of the Internet. Secondly, people must consume to survive, which is also the most basic human need. However, due to technological limitations, people could only consume on the spot before. Ant Financial (Alipay) broke through the restrictions. It relied on the Internet and successfully used its technological advantages to develop a thirdparty payment platform successfully. Subsequently, Ant Financial began to diversify financial services, such as using Huabei to help small and micro enterprises with loan services, Yu'e Baolai to help ordinary people with wealth management and investment, etc.; so far, only Alipay under Ant Financial has it. More than 1 billion users. Coupled with the enormous advantages of Internet technology, Ant Financial still has substantial development prospects through the "Internet + Finance" third-party service platform model.

Ant Financial is also facing tremendous competitive pressure, with two main competitors. First, Internet companies [9]. As we all know, there are two systems in China's Internet industry: Ali and Tencent. This is because almost all well-known companies in the Internet industry are inextricably linked with these two companies - for example, Alipay and Tencent's WeChat Pay, Yu'ebao, and Tenpay's Tenpay. Second, traditional financial companies. Since Ant Financial's primary business is in the financial industry, traditional banking (Agricultural Bank, Industrial and Commercial Bank of China), securities (Northeast Securities), insurance (Ping An of China), and other financial-related industries will receive a considerable impact. Then, these companies are bound to become competitors of Ant Financial to survive. However, Ant Financial has the advantages of an early start, a wide range of fields, and a large number of users, which also allows it to continue to develop while always having colossal development potential and space.

\subsection{Context}

In the future, an Internet finance company must be compliant, pay attention to user experience, and serve the real economy in the long run. First, focus on user experience. This is also the most significant advantage of Ant Financial because it has the support of Alibaba. As one of the largest Internet companies in China, Alibaba attaches great importance to and succeeds in user experience. Second, compliance. From the failure of Ant Financial to go public, it can be seen that it needs more rigorous related services and product management systems. Since its products are all based on the Internet, it is necessary to formulate a more stringent regulatory system and system than before, but this is not available in Ant Financial. Third, it serves the real economy. This is probably the biggest problem facing Ant Financial. 
Internet finance advocates and advocates the concept of allowing advanced consumption, but the pillar of the national economy is still the real economy in the final analysis. If the Internet economy represented by advanced consumption is allowed to drive consumption, the country's future development potential will likely be overdrawn. As the most significant Internet finance company, Ant Group is strictly censored by the state. Therefore, the most crucial thing for Ant Financial is to find a way to balance the real economy and the Internet economy.

However, Ant Financial also has its advantages. For example, it has established a very complete and diversified product system, service system, and market system. More importantly, it has won the trust of ordinary users, and it also provides a new development path for small and micro-enterprises. In addition, when Ant Financial will separate part of its financial business after rectification, it will also comply with relevant national regulations and play a leading role in developing the real economy. When the Internet finance industry becomes more mature, the barriers to entry into the industry will also increase substantially. In addition, Ant Financial itself has a vast customer base, and once the rectification is successful, few companies can match it.

\section{DISCUSSION}

Investing in a company depends on industry development performance, company performance and financial status, and national policies. Next, we will conduct a detailed analysis of Ant Financial from the above four perspectives.

\subsection{Industry Development}

There is no doubt that it is worth the investment from the perspective of industrial development. In China, the scale of the Internet financial market in 2020 officially exceeded RMB 10 trillion, of which the scale of the payment market reached RMB 9.22 trillion. This is mainly due to the rapid development of e-commerce, and the income from payment platforms is also obtained. As of 2016, China's financial users reached 500 million. With the further in-depth management of Internet finance and the further growth of Internet users, the industry will continue to develop. However, due to the enormous scale of the industry, many illegal businesses and companies take advantage of the public's wealth to engage in fraudulent activities. In recent years, this has also greatly affected the lives of many people. However, as the country pays more attention to the industry, the problem will be solved.

\subsection{Company performance and financial status}

From this point of view, it is not suitable for investment now. Although the first financial report in 2017 was released, Ant Financial's operating income, profit, and total assets have maintained a strong growth momentum. Even a single operating income exceeds the total income of some listed companies. However, since the second quarter of 2020, no financial report has been released due to the termination of a listing.

So far, Ant Financial has gone through seven rounds of financing (Table 2). In April 2014, the first round of strategic financing attracted two giant companies, Jianxin Investment and PICC. In May 2015, the Pre-A round of financing attracted RMB 219 million of investment from Haier Capital. In July 2015, Series A received RMB 12 billion in financing with a valuation of USD 45 billion. Most companies are China's top companies, such as China Life, Xinhua Insurance, China Development Bank Capital, PICC, Etc [10]. In September 2015, the second round of strategic financing was invested by China Post Capital. In April 2016, China Investment Corporation, CCB Trust, Chunhua Capital, E Fund, and other top funds, capital, or investment companies in China made investments. A total of US $\$ 4.5$ billion was invested in this round, and the valuation rose to US\$60 billion. In February 2018, Alibaba independently invested in the third round of strategic financing as a significant shareholder. In June 2018, the Pre-IPO made Ant Financial's valuation reach an astonishing US $\$ 150$ billion. Because, as the last round of financing before listing, this round attracted a total of 140 top global capital from Malaysia's Khazanah Holdings, Canadian Pension Fund Investment Corporation, Temasek, Pan Atlantic Capital Group, T. Rowe Price's funds, and Carlyle Investment Group. Billion dollars in investment. However, the failure to go public last year had a tremendous negative impact on the company's investment prospects. 
Table 2. financial round for the firm

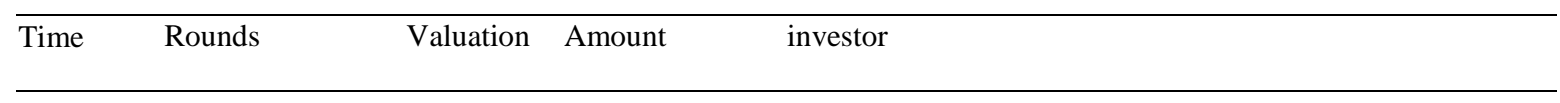

\subsubsection{Pre-IPO \$150 billion $\$ 14$ billion}

2018.02.01 Strategic financing

2016.04 .26

B round

$\$ 60$ billion

$\$ 4.5$ billion

2015.09.05 Strategic financing
A round

\$45 billion

12 billion $\mathrm{rmb}$

2015.05.01

Pre-A round

0.219 billion $\mathrm{rmb}$
GIC Singapore Government Investment Corporation

Khazanah Holdings

Warburg Pincus Investment

Silver Lake Capital T. Rowe

PriceJanchor Capital

Discovery Capital management

Baillie Gifford

Canadian Pension Fund CPPIB

Transatlantic Investment

Carlyle Investments

Temasek Temasek

Original shareholders

Alibaba

China Investment Corporation

CCB Trust

China Life Insurance

Zhongjin Jiazi

China Post Capital

China Development Bank Financial

Spring China Capital

Hanford Capital

E Fund

PetroChina Capital

National Social Security Fund

China Development Fund

Spring China Capital

China Life Insurance

People's Insurance Group of China

Xinhua Insurance

Gimpo Investment

China Post Capital

Yunfeng Fund

China Pacific Life Insurance Company Limited

Haier Capital

\subsection{National Policy}

From the perspective of national policies, Ant Financial is worth investing in in the future. The Internet finance industry will affect the development of the country in the industry. Therefore, the country's popular trends regarding the industry's policies. Therefore, the most crucial thing in the investment industry is knowledge and strategic national policies. Look, the state focuses on Internet business and will supervise financial activities as a framework. From the perspective of the Internet, Ant Financial is worth the investment because it is supported by world-class technology like Alibaba. However, if finance is viewed from a financial company's perspective, the answer is unclear. The primary reason why Ant Financial is prohibited from appearing in the world is that it does not 
comply with the relevant regulations of the financial industry, which is of great significance. Therefore, we continue to pay attention to the country's future policy trends.

\section{CONCLUSION}

This article first introduces the basic overview of Internet finance and the development in China today. According to the general situation, it is very beneficial to invest in Internet finance regardless of the industry itself or China's overall environment. So, the most important thing to invest in an industry is to choose a company. Thus, we have led to the theme, that is, the feasibility of investing in Ant Financial. Subsequently, we analyzed the feasibility of investing in the company using the POCD analysis method.

We have found that Ant Financial has been very smooth from its birth to the middle of last year through data analysis and research. It can be said that it is an investment opportunity that is almost always profitable. However, in November last year, he was interviewed by the China Banking Regulatory Commission for rectification because it did not comply with the relevant listing regulations of the Chinese government. This also means that the decision about investment needs to be reconsidered. Therefore, we concluded that we should not make any investment related to Ant Group for the time being, and all subsequent related matters should be based on the results of the Chinese government's processing.

At the same time, there is still room for improvement in this paper. For example, we lack data analysis on the attitudes of ordinary investors to Ant Financial shortly (referring to the suspension of listing). In the paper, we are concerned about the industry, government, and enterprises. They have done an indepth analysis, but they lack the analysis of ordinary investors. In the future, we will collect more information about this aspect to make the research on the subject of the thesis more comprehensive and complete.

\section{REFERENCES}

[1] Liu, Y., Zhu, R., Department, S. M., \& Academy, S. M. (2014). Internet finance,small \& microenterprise financing and credit reference system deepening. Credit Reference.

[2] Xie, P. , Zou, C. , Liu, H. , Corporation, C. I. , \& Programme, T. P. . (2015). The fundamental theory of internet finance. Journal of Financial Research.

[3] Hou, X., Gao, Z., \& Wang, Q. (2016). Internet finance development and banking market discipline: evidence from china. JOURNAL OF FINANCIAL STABILITY, 22, 88-100.
[4] Jing, W. (2017). "stir-frying" internet finance: financialization and the institutional role of financial news in china. International Journal of Communication, 11.

[5] JianguoXu. (2017). China's internet finance: a critical review. China \& World Economy, 25(4), 78-92.

[6] Dong, J., Yin, L., Liu, X., Hu, M. , \& Liu, L. . (2020). Impact of internet finance on the performance of commercial banks in china. International Review of Financial Analysis, 72, 101579 .

[7] Michayluk, D., \& Neuhauser, K. (2010). Is liquidity symmetric? a study of newly listed internet and technology stocks. International Review of Finance, 8(3-4), 159-178.

[8] Hand, J. (2001). The role of book income, web traffic, and supply and demand in the pricing of u.s. internet stocks. Review of Finance (3), 315317(3)

[9] Li, W., Cheng, Y. , \& Fang, Q. . (2020). Forecast on silver futures linked with structural breaks and day-of-the-week effect. The North American Journal of Economics and Finance, 53, 101192.

[10] Olsen, Robert, A., Dewally, \& Michael. (2004). Internet investment advice: investing with a rock of salt. Journal of Behavioral Finance, 5(1), 67-67. 